УДК 343.12:341.4

DOI: https://doi.org/10.26642/jen-2020-4(94)-131-141

Д.О. Грицишен, д.е.н., проф.

Державний університет «Житомирська політехніка»

\title{
Механізм взаємодії з міжнародними правоохоронними організаціями у сфері запобігання та протидії економічній злочинності
}

\begin{abstract}
У статті доведено, щзо система правоохоронної діяльності України має бути побудована з метою налагодження ефективних взаємозв'язків з міжнародними правоохоронними організаціями. Наведено перелік та охарактеризовано глобальні й регіональні міжнародні правоохоронні організащіi, а саме: Інтерпол, Асеанапол, Афріпол, Свропол, Амеріпол, GCCPOL, АІМС. Визначено, щзо сьогодні Україна співпрацює з двома такими організаціями: глобальною Інтерпол (в Украӥні функціонує Національне центральне бюро на базі Міністерства внутрішніх справ Украӥни) і регіональною - Свропол (Украӥна направила офіцерів зв'язку до ичієї міжнародноі правоохоронної організаціï). Розглянуто особливості функціонування зазначених правоохоронних організацій та особливості їх взаємодї з вітчизняними правоохоронними органами у сфері запобігання та протидії економічній злочинності.

Проаналізовано хронологію розвитку Інтерполу як міжнародного правоохоронного органу. Досліджено організащійну структуру Інтерполу та охарактеризовано кожну ї складову: Генеральну Асамблею, Виконавчий комітет, Президента Інтерполу, Генеральний секретаріат. Наведено характеристику діяльності директоратів Генерального секретаріату Інтерполу. Ідентифіковано механізми державної політики, щу мають врегулювати діяльність вітчизняних правоохоронних органів у контексті відповідності діяльності Інтерполу. Надано характеристику глобальним иілям зазначеного правоохоронного органу й напрямам трансформації державної політики у сфері запобігання та протидії економічній злочинності. Досліджено особливості державного регулювання процедур взаємодї з Інтерполом. Проаналізовано розвиток Сврополу як регіонального правоохоронного органу.
\end{abstract}

Ключові слова: економічна злочинність; протидія; правоохоронна діяльність; механізм; міжнародні правоохоронні організащіі;; Інтерпол; Європол.

Актуальність теми. Важливе значення у формуванні та реалізації державної політики у сфері запобігання та протидії економічній злочинності займають міжнародні суб'єкти, особливо міжнародні правоохоронні організації. Це обумовлено тим, що злочинність в цілому та економічна злочинність зокрема не мають державних кордонів, а в окремих випадках взаємодія між державами через функціонування міжнародних правоохоронних організацій дозволяє вирішити деякі процесуальні питання. «Злочинність на сучасному етапі розвитку суспільства становить надзвичайно серйозну небезпеку для його подальшого розвитку. Вийшовши за межі кордонів певної держави, злочинність набула небезпечного транснаціонального характеру. Сьогодні уряду будь-якої держави (незалежно від засобів і ресурсів, якими вона володіє) украй складно вживати заходів, ефективних для боротьби 3 транснаціональною організованою злочинністю, не вдаючись до тієї або іншої форми міжнародного співробітництва. Усі країни світу мають усвідомлювати, що жодна 3 них не захищена від зіткнення 3 транснаціональною злочинністю» [1, с. 10]. Таким чином, для науки державного управління виникає низка питань щодо формування інституційних зв'язків із міжнародними правоохоронними організаціями у сфері запобігання та протидії економічній злочинності.

Аналіз останніх досліджень та публікацій, на які спирається автор. Питання розроблення механізму взаємодії з міжнародними правоохоронними організаціями у сфері запобігання та протидії економічній злочинності досить рідко порушувалися в межах наукових досліджень у сфері державного управління. Тому за основу було взято праці вітчизняних та зарубіжних вчених, що вивчали юридичні й дипломатичні аспекти взаємодії з міжнародними правоохоронними організаціями в контексті запобігання та протидії економічній злочинності. Цьому питанню присвячено праці О.І. Виноградовоі, О.Г. Волеводзи, Т.С. Гавриша, Л.Н. Галенської, О.М. Джужі, Ю.Ф. Іванова, Л.Д. Тимченка, В.М. Волженкіна, В.А. Карташкіна, І.І. Лукашука, С.В. Черніченка, П.Д. Біленчука, С.Є. Єркенова та інших.

Метою статті є дослідження та розроблення механізму взаємодії з міжнародними правоохоронними організаціями у сфері запобігання та протидії економічній злочинності.

Викладення основного матеріалу. Україна не може стояти осторонь як від глобалізаційних процесів, так і від процесів міжнародного співробітництва щодо запобігання та протидії економічній злочинності. Система правоохоронної діяльності України має бути побудована таким чином, щоб налагодити ефективні взаємозв'язки з міжнародними правоохоронними організаціями.

(C) Д.О. Грицишен, 2020 
«В сучасних умовах неодноразово підтверджувалася необхідність колективних зусиль світової спільноти по розробці адекватних засобів і методів протидії сучасним загрозам кримінального характеру. Зазначена мета в основному досягається зближенням національних законодавств, прийняттям єдиних критеріїв класифікації злочинів, однакової правозастосовної практики, а також виробленням загальних принципів і єдиної стратегії у співпраці по лінії експертно-криміналістичної та оперативно-розшукової діяльності. Особливістю такої співпраці є процес поступового перенесення взаємодії та інтеграції держав на регіональний рівень, який сам собою не скасовує глобалізацію, оскільки запорукою успіху протидії злочинності є включення держав світу в глобальну правоохоронну систему. Міжнародні організації та режими покликані не змагатися, а доповнювати один одного. Формування балансу інтересів «глобалізація - регіоналізація» за рішеннями перерахованих вище завдань веде до інноваційних подань концептуальних засад співробітництва держав у сфері експертно-криміналістичної та оперативнорозшукової діяльності, сприяє підвищенню його ефективності та появі нових криміналістичних засобів і методів розкриття й розслідування злочинів» [2, с. 48].

Отже, важливе значення сьогодні покладається на міжнародне співробітництво у сфері запобігання та протидій економічній злочинності, яке за суб'єктною ознакою поділяється на глобальне та регіональне. Метою цього дослідження $є$ оцінка взаємодії вітчизняних правоохоронних органів 3 міжнародними правоохоронними організаціями. Такі правоохоронні організації можуть діяти як в цілому у світі - глобальні, так і на території певного регіону - регіональні (табл. 1).

«Розуміння державами необхідності міжнародного поліцейського співробітництва і його успішна реалізація на універсальному рівні спонукало становлення і розвиток тенденції регіонального поліцейського співробітництва. Регіональний рівень співпраці держав з будь-яких питань, безумовно, дає можливість враховувати специфічні особливості держав певного регіону, оперативніше вирішувати проблеми, що виникають, здійснювати реальне наповнення такої взаємодії, а також в подальшому забезпечити реалізацію й виконання прийнятих розпоряджень і міжнародних зобов’язань» [3].

Глобальні та регіональні міжнародні правоохоронні організації

Табличя 1

\begin{tabular}{|c|c|}
\hline Організація & Характеристика \\
\hline \multicolumn{2}{|r|}{ Глобальні правоохоронні організації } \\
\hline Інтерпол & $\begin{array}{l}\text { Міжнародна організація кримінальної поліції, що функціонує у } 194 \text { країнах світу, зі } \\
\text { штаб-квартирою у Ліоні }\end{array}$ \\
\hline \multicolumn{2}{|r|}{ Регіональні правоохоронні організації } \\
\hline Асеанапол & Заснована у 1981 році та має 10 країн-членів Південно-Східної Азії \\
\hline Афріпол & $\begin{array}{l}\text { Африканський механізм поліцейського співробітництва зі штаб-квартирою в Алжирі, } \\
\text { що налічує } 54 \text { члени }\end{array}$ \\
\hline Європол & $\begin{array}{l}\text { Агенція Свропейського Союзу з питань правоохоронної співпраці, що була створена } \\
\text { у } 1998 \text { році для обслуговування держав-членів ЄС }\end{array}$ \\
\hline Амеріпол & $\begin{array}{l}\text { Поліцейська громада Америки, що була заснована у } 2007 \text { році й складається } 3 \\
28 \text { поліцейських сил та } 19 \text { агентств-спостерігачів }\end{array}$ \\
\hline GCCPOL & $\begin{array}{lllll}\text { Правоохоронний орган Генерального секретаріату Ради співробітництва для } \\
\text { арабських держав Перської затоки, що існує з } 1981 \text { року }\end{array}$ \\
\hline AIMC & $\begin{array}{l}\text { Арабська рада міністрів внутрішніх справ, що заснована у } 1982 \text { році та має на меті } \\
\text { розвивати й зміцнювати співпрацю й координацію зусиль між арабськими державами } \\
\text { у сфері внутрішньої безпеки та запобігання злочинам }\end{array}$ \\
\hline
\end{tabular}

Сьогодні Україна співпрацює з двома організаціями, а саме:

- глобальною - Інтерпол. В Україні функціонує Національне центральне бюро на базі Міністерства внутрішніх справ України;

- регіональною - Європол. Україна направила офіцерів зв'язку до цієї міжнародної правоохоронної організації.

Розглянемо особливості функціонування та взаємодії зазначених правоохоронних організацій із вітчизняними правоохоронними органами у сфері запобігання та протидії економічній злочинності.

Інтерпол. «Важливим моментом у діяльності МККП, який має значення і в наш час, були правила функціонування Комісії з повною повагою до національного суверенітету держав, що беруть участь у іiі діяльності. Поліцейські однієї держави, як було закріплено в найперших статутних документах, не могли за власним бажанням та ініціативою продовжувати свої дії в межах національних кордонів іншої країни. МККП була покликана слугувати інформаційним i координаційним центром та зверталася до відповідних держав, що належать до їі складу, з проханнями щодо можливостей затримання і швидкої видачі (екстрадиції) заарештованих злочинців. Члени Комісії боролися із загальною кримінальною злочинністю і не втручалися у політичні, расові й релігійні питання. Цей принцип і зараз залишається основоположним в діяльності Інтерполу» [4]. 
Інтерпол як міжнародна правоохоронна (поліцейська) організація розвивалася впродовж минулого та теперішнього століття як в географічному напрямі, так і у функціональному. А саме щодо механізмів взаємодії з національними правоохоронними органами, методів оперативно-розшукової діяльності, способів та методів вивчення і розслідування злочинів в цілому та економічних злочинів зокрема. Еволюцію Інтерполу наведено в таблиці 2.

Таблиия 2

Хронологія розвитку Інтерполу як міжнародного правоохоронного органу

\begin{tabular}{|c|c|}
\hline Рік & Подія \\
\hline 1923 & Створено Міжнародну комісію кримінальної поліції зі штаб-квартирою у Відні \\
\hline 1927 & $\begin{array}{l}\text { Четвертою Генеральною Асамблеєю в Амстердамі прийнято резолюцію, згідно з якою кожна країна- } \\
\text { член зобов’язана створити центральний контактний пункт у своїй поліцейській структурі }\end{array}$ \\
\hline 1930 & $\begin{array}{l}\text { Створено спеціалізовані відділи, які займалися веденням судимості, справами щодо підробки валюти та } \\
\text { паспортів }\end{array}$ \\
\hline 1932 & Введено посаду Генерального секретаря \\
\hline 1935 & Створено міжнародну радіомережу для використання органами кримінальної поліції \\
\hline 1938 & Тимчасово припинено існування через захоплення нацистами \\
\hline 1946 & Відновлено роботу зі штаб-квартирою в Парижі \\
\hline 1947 & Опубліковано перше червоне кодоване повідомлення \\
\hline 1956 & $\begin{array}{l}\text { МККП перейменовано в Міжнародну організацію кримінальної поліції (INTERPOL) та прийнято нову } \\
\text { конституцію }\end{array}$ \\
\hline 1958 & Прийнято Фінансові правила Інтерполу \\
\hline 1959 & Проведено міжнародну зустріч з питань торгівлі наркотиками за участю директора ООН \\
\hline 1963 & Проведено першу регіональну конференцію для країн-членів у Ліберії \\
\hline 1972 & Інтерпол визнано міжнародною організацією \\
\hline 1982 & $\begin{array}{l}\text { Генеральною Асамблеєю прийнято Правила про міжнародну поліцейську співпрацю та контроль за } \\
\text { архівами Інтерполу }\end{array}$ \\
\hline 1986 & Здійснено напад екстремістського угрупування на офіс Генерального секретаріату \\
\hline 1989 & Генеральний Секретаріат переміщено до Ліона \\
\hline 1990 & $\begin{array}{l}\text { Запущено систему зв'язку Х.400, що дозволяє Національним центральним бюро надсилати електронні } \\
\text { повідомлення один одному та Генеральному секретаріату }\end{array}$ \\
\hline 1992 & Впроваджено автоматизовану систему пошуку для віддаленого пошуку у базах даних Інтерполу \\
\hline 1993 & $\begin{array}{l}\text { Створено аналітичний підрозділ кримінальної розвідки для вивчення зв'язків між підозрюваними, } \\
\text { злочинами та місцезнаходженням }\end{array}$ \\
\hline 1999 & Арабську прийнято четвертою офіційною мовою Інтерполу \\
\hline 2000 & Запроваджено автоматичну систему ідентифікації відбитків пальців \\
\hline 2001 & $\begin{array}{l}\text { Організація розпочала діяти } 24 \text { години на добу } 7 \text { днів на тиждень після терактів на Сполучені Штати } \\
\text { Америки } 11 \text { вересня }\end{array}$ \\
\hline 2002 & $\begin{array}{l}\text { Запущено глобальну поліцейську комунікаційну систему I-24/7, що надало всім країнам-членам надійну } \\
\text { платформу для обміну й доступу до баз даних та інформації }\end{array}$ \\
\hline 2002 & Запущено базу даних про втрачені прохідні документи (паспорти) \\
\hline 2002 & Створено базу ДНК \\
\hline 2003 & $\begin{array}{l}\text { Створено Командно-координаційний центр, щоб забезпечити контактну точку для будь-якої країни- } \\
\text { члена, яка терміново шукає інформацію поліції або стикається з кризовою ситуацією }\end{array}$ \\
\hline 2004 & Відкрито спеціальне представництво при ООН у Нью-Йорку \\
\hline 2005 & $\begin{array}{l}\text { Опубліковано перше Спеціальне повідомлення Ради безпеки ООН щодо заморожування активів, } \\
\text { заборони на виїзд та ембарго на озброєння }\end{array}$ \\
\hline 2005 & $\begin{array}{l}\text { Розроблено нову технологію MIND / FIND, яка дозволяє країнам надавати своїм передовим офіцерам } \\
\text { доступ у реальному часі до баз даних }\end{array}$ \\
\hline 2007 & Створено Глобальний навчальний центр Інтерполу \\
\hline 2010 & $\begin{array}{l}\text { Перша операція «Інфра» об’єднала чиновників багатьох країн для пошуку та арешту серйозних } \\
\text { довгострокових міжнародних втікачів }\end{array}$ \\
\hline 2015 & $\begin{array}{l}\text { В Сінгапурі відкрито Глобальний інноваційний комплекс Інтерполу. Це науково-дослідна установа для } \\
\text { виявлення злочинів і злочинців та інноваційного навчання й оперативної підтримки }\end{array}$ \\
\hline
\end{tabular}

Сучасне розуміння функціонування Інтерполу полягає в тому, що це $є$ найбільшою та найефективнішою міжнародною правоохоронною (поліцейською) організацією. Сьогодні вона налічує 194 країни-учасниці, з правоохоронними органами яких налагоджено ефективні взаємозв'язки, у тому числі щодо запобігання та протидії економічній злочинності. «Всупереч поширеній у суспільстві думці, Інтерпол не $€$ окремим наддержавним поліцейським органом, який самостійно займається розслідуваннями найбільш небезпечних міжнародних злочинів, маючи в своєму штаті «армію» власних слідчих та спецназу. Тобто, співробітники Інтерполу не займаються, власне, слідчою та оперативною 
роботою в пошуках злочинців по всьому світові. Хоча в організації є певні «групи реагування», але це, скоріше, не спецназ, а інструктори, які за необхідністю та виключно за згодою «приймаючої країни» допомагають поліцейським держав-членів в ситуаціях, коли, наприклад, останнім бракує ресурсів та досвіду для затримання найбільш небезпечних злочинців. По суті, головною функцією Інтерполу $є$ створення та підтримка різноманітних баз даних, якими можуть користуватися правоохоронні органи країн-членів організації. Приміром, це $є$ бази даних фальшивомонетників, членів наркокортелів, викрадених автомобілів, викрадених витворів мистецтва і т. д.» [5].

Особливістю діяльності Інтерполу є те, що найбільш важливі та стратегічні рішення приймають колегіально. В цілому організаційна структура Інтерполу є чіткою та ефективною, а кожна країнаучасниця має національне центральне бюро, що зазвичай діє при профільному міністерстві. Наприклад в Україні бюро функціонує при Міністерстві внутрішніх справ України.

Організаційну структуру Інтерполу наведено на рисунку 1.

Надамо характеристику кожній складовій організаційної структури Інтерполу:

- Генеральна Асамблея. Вищим керівним органом Інтерполу $\epsilon$ Генеральна Асамблея, яка збирається щороку (тривалість сесії 4 дні), а до їі складу належать представники кожної країни-учасниці (один або декілька представників, які є керівниками поліції або вищими посадовцями профільного міністерства чи відомства). «Генеральна Асамблея приймає рішення тільки на сесіях у формі резолюцій чи шляхом запису в протокол (обрання посадових осіб, рішення про прийняття нових членів, затвердження програми діяльності на наступний рік, вибір місця проведення чергової сесії). За загальним правилом Генеральна Асамблея приймає рішення простою більшістю голосів країн-учасниць, присутніх і голосуючих на засіданні» [6].

Можна виокремити такі основні функції Генеральної Асамблеї: регулювання діяльності Інтерполу відповідно до потреб країн-учасниць; перегляд та затвердження його програми діяльності; затвердження фінансової політики на наступний рік; обрання членів виконавчого комітету. Генеральна Асамблея приймає рішення у формі резолюції, за яку голосують ії члени згідно з принципом: одна країна - один голос. Варто зауважити, що залежно від предмета рішення та його важливості визначають результати голосування, а саме - простою більшістю (50\%+ 1 голос) або $2 / 3$;

- Виконавчий комітет Інтерполу. Виконавчий комітет Інтерполу є керівним органом, метою функціонування якого $є$ нагляд за виконанням рішень Генеральної Асамблеї та адміністрування роботи Генерального секретаріату. Членами виконавчого комітету є Президент Інтерполу, три віцепрезиденти та дев’ять делегатів, що обираються Генеральною Асамблеєю. Станом на 2020 рік делегатами виконавчого комітету є: Халед Джаміль Аль Матерієн (Йорданія); Ахмед Нассер Аль-Раїсі (Об'єднані Арабські Емірати); Жан-Жак Колумбі (Франція); Ектор Еспіноса Валенсуела (Чилі); Роджеріо Галлоро (Бразилія); Роберт Гірао Байлен (Андора); Дестіно Педро (Ангола); Олушола Камар Субайр (Нігерія); Жанін Ван ден Берг (Нідерланди). Крім того, до складу належать три віцепрезиденти: сьогодні це представники Алжиру та Чеської Республіки, а посада віцепрезидента з питань Америки - вакантна. Основними завданнями Виконавчого комітету, що передбачено конституцією Інтерполу, є контроль виконання рішень Генеральної Асамблеї; підготовка порядку денного для сесій Генеральної Асамблеї; подання на розгляд Генеральної Асамблеї будь-якої програми роботи чи проєкту, які вона вважає корисними; нагляд за адміністрацією та роботою Генерального секретаря;

- Президент Інтерполу. Президент Інтерполу обирається строком на 4 роки на сесії Генеральної Асамблеї. Варто зауважити, що Президент не $є$ штатною посадою, а його робота не оплачується. Тобто обраний Президент залишає за собою посаду в національних правоохоронних органах країни, яку він представляє в Генеральній Асамблеї. Основні функції Президента Інтерполу такі: головування на сесіях Генеральної Асамблеї та на засіданнях виконавчого комітету; забезпечення відповідності діяльності Інтерполу рішенням Генеральної Асамблеї; підтримка постійного контакту з Генеральним секретарем;

- Генеральний секретаріат. Генеральний секретаріат - постійно діючий адміністративний та виконавчий орган Інтерполу. Очолює зазначений орган Генеральний секретар. Для визначення особливостей діяльності Генерального секретаріату нами було вивчено статут Інтерполу (ст. 26), в якому зазначено його функціональну роль: «а) втілює в життя рішення Генеральної Асамблеї і Виконавчого комітету; б) $є$ міжнародним центром 3 боротьби зі злочинністю; в) діє як спеціалізований та інформаційний центр; г) здійснює ефективне керівництво діяльністю організації; г) підтримує контакти 3 національними та міжнародними органами, при цьому питання, пов'язані з розшуком злочинців, вирішуються через Національні центральні бюро; д) публікує матеріали, які можуть вважатися доцільними; е) бере на себе обов'язки робочого секретаріату на сесіях Генеральної Асамблеї, Виконавчого комітету і будь-якого іншого органу організації; є) розробляє проєкт плану роботи на наступний рік, що виноситься на розгляд і затвердження Генеральною Асамблеєю та Виконавчим комітетом; ж) за можливості підтримує постійний безпосередній зв'язок з Президентом організації» [7]. 


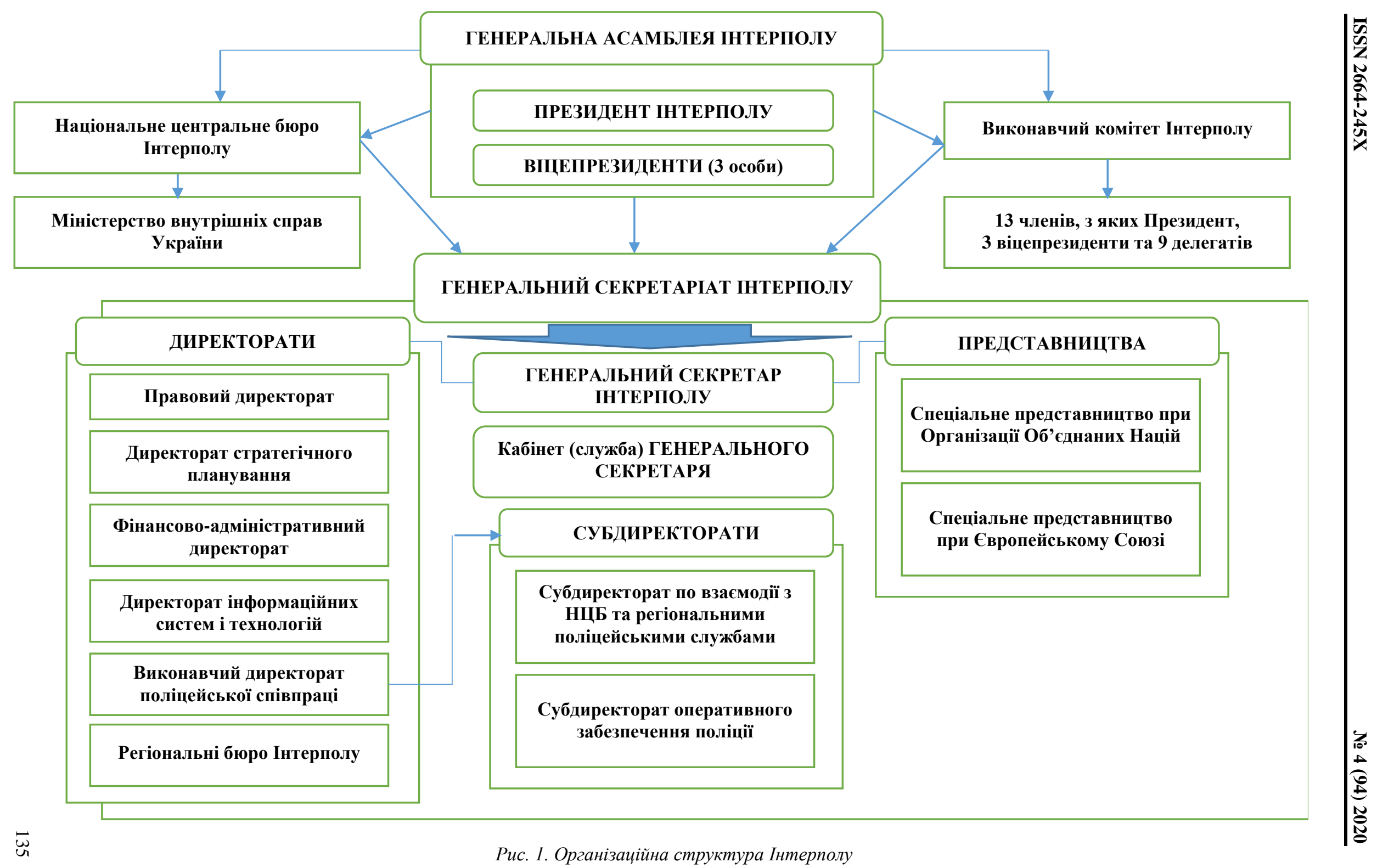


До складу Генерального секретаріату належать директорати (табл. 3) та представництва:

- $\quad$ в Свропейському Союзі: «Офіс Спеціального представника Інтерполу при Свропейському Союзі, що базується в Брюсселі, працює над тим, щоб проблеми глобальної правоохоронної діяльності були належним чином представлені в ініціативах та рішеннях ЄС. Цілі офісу: сприяти співробітництву з СС у сферах, що стосуються правоохоронних органів, щоб забезпечити найсильніше можливе міжнародне співробітництво у галузі безпеки та проти злочинності й тероризму, а також гарантувати, що кожна сторона отримає повну вигоду від того, що може запропонувати інша сторона; допомагати проєктним командам Інтерполу у визначенні варіантів фінансування $\mathrm{CC}$, де це доречно» [8];

- $\quad$ в Організації Об’єднаних Націй: Представництво Інтерполу в ООН було створено у 2004 році. Так ООН може використовувати інструменти та послуги Інтерполу, який, в свою чергу, через ООН може доносити проблеми злочинності до політиків. Основними напрямами співпраці є боротьба 3 тероризмом, торгівлею людьми, наркотиками та сукупністю видів економічної злочинності.

Таблиия 3

Характеристика діяльності директоратів Генерального секретаріату Інтерполу

\begin{tabular}{|c|c|}
\hline Директорат & Характеристика діяльності \\
\hline $\begin{array}{l}\text { Правовий } \\
\text { директорат }\end{array}$ & $\begin{array}{l}\text { Веде консультаційну роботу з питань права, що стосуються діяльності Інтерполу та } \\
\text { міжнародної співпраці у боротьбі зі злочинністю; готує проєкти правових актів та угод } 3 \\
\text { державами і міжнародними організаціями. У взаємодії } 3 \text { іншими структурними } \\
\text { підрозділами здійснює дослідницьку та аналітичну роботу, готує рекомендації, } \\
\text { узагальнює і готує до опублікування міжнародну кримінальну статистику, випускає } \\
\text { офіційне видання Інтерполу -«Міжнародний огляд кримінальної поліції» }\end{array}$ \\
\hline $\begin{array}{c}\text { Директорат } \\
\text { стратегічного } \\
\text { планування }\end{array}$ & $\begin{array}{l}\text { С аналітичним підрозділом Генерального секретаріату і здійснює стратегічне планування } \\
\text { діяльності Інтерполу. У міру накопичення значних обсягів інформації в базах даних } \\
\text { Інтерполу стало необхідним створення інструмента управління ними та їх оперативного } \\
\text { опрацювання. Таким інструментом є система централізованого управління I-Link. Вона } \\
\text { дозволяє автоматизувати процес накопичення, обробки та звернення до інформацї̈ в базах } \\
\text { даних Інтерполу, проводити їі аналіз, встановлювати зв’язки між інформацією } 3 \text { різних } \\
\text { джерел шляхом використання механізму перехресних запитів. Названий директорат } \\
\text { забезпечує і контролює роботу цієї системи }\end{array}$ \\
\hline $\begin{array}{c}\text { Фінансово- } \\
\text { адміністративний } \\
\text { директорат }\end{array}$ & $\begin{array}{l}\text { Здійснює адміністративне, кадрове, матеріально-технічне, господарське, фінансове та } \\
\text { інше забезпечення діяльності Інтерполу; веде організаційну підготовку сесій Генеральної } \\
\text { Асамблеї і засідань інших органів організації, конференцій, прийомів делегацій; } \\
\text { організовує діловодство (переклад, підготовку документів, відправку кореспонденції } \\
\text { тощо) }\end{array}$ \\
\hline $\begin{array}{c}\text { Директорат } \\
\text { інформаційних } \\
\text { систем і технологій }\end{array}$ & $\begin{array}{l}\text { Здійснює вивчення, розробку і застосування телекомунікаційного та комп’ютерного } \\
\text { обладнання, необхідного для функціонування організації. Цей директорат технічно } \\
\text { забезпечує функціонування стандарту зв’язку I-24/7 - глобальної системи зв'язку та } \\
\text { обміну інформацією Інтерполу, доступної } 24 \text { години на добу } 7 \text { днів на тиждень, що } \\
\text { дозволяє передавати не тільки текстові, але й графічні та інші документи }\end{array}$ \\
\hline $\begin{array}{l}\text { Виконавчий } \\
\text { директорат } \\
\text { поліцейської } \\
\text { співпраці }\end{array}$ & $\begin{array}{l}\text { Є головним підрозділом Генерального секретаріату; здійснює поточну діяльність } 3 \text { питань } \\
\text { міжнародної співпраці поліцейських відомств різних країн у боротьбі зі злочинністю }\end{array}$ \\
\hline Регіональні бюро & $\begin{array}{l}\text { Сформовані для гарантування оперативності діяльності організації в регіонах: } \\
\text { Центральній Америці (Сальвадор, м. Сан-Сальвадор), Східній Африці (Кенія, м. Найробі), } \\
\text { Південній Америці (Аргентина, м. Буенос-Айрес), Західній Африці (Кот-д’Івуар, } \\
\text { м. Абіджан), Південній Африці (Зімбабве, м. Хараре), Центральній Африці (Камерун, } \\
\text { м. Яунде), Південно-Східній Азії (Таїланд, м. Бангкок) }\end{array}$ \\
\hline
\end{tabular}

Загальні напрями розвитку державної політики у сфері запобігання та протидії економічній злочинності в контексті діяльності Інтерполу варто розглядати з огляду на цілі та стратегії його розвитку. Так за офіційними даними Інтерпол переслідує сім глобальних цілей, наведених у таблиці 4, та п’ять стратегічних напрямів, зазначених нижче:

1. Виконувати функцію світового інформаційного центру для співпраці правоохоронних органів;

2. Забезпечувати найсучасніші поліцейські можливості, які надають підтримку країнам-членам у боротьбі та запобіганні транснаціональним злочинам;

3. Впроваджувати інноваційні підходи до поліцейської діяльності у світі;

4. Максимізувати роль Інтерполу в межах Глобальної архітектури безпеки;

5. Консолідувати ресурси та структури управління для підвищення ефективності роботи.

У контексті зазначених напрямів пропонується ідентифікувати механізми державної політики, що покликані врегулювати діяльність вітчизняних правоохоронних органів відповідно до діяльності Інтерполу. 
Глобальні изілі Інтерполу та напрями трансформацї державної політики в сфері запобігання і протидії економічній злочинності

\begin{tabular}{|c|c|}
\hline Напрями реалізації цілей & Вплив на державну політику \\
\hline \multicolumn{2}{|l|}{ Ціль 1: Протидія загрозі тероризму } \\
\hline $\begin{array}{l}-\quad \text { Виявлення та арешт підозрюваних у тероризмі. } \\
-\quad \text { Посилення платформи обміну розвідданими. } \\
-\quad \text { Запобігання терористичному руху, мобільності злочинців. } \\
-\quad \text { Відстеження та припинення фінансових потоків і джерел зброї }\end{array}$ & $\begin{array}{l}\text { Основними завданнями державної } \\
\text { політики має стати всебічне } \\
\text { впровадження рекомендацій FATF } \\
\text { щодо протидії фінансування } \\
\text { тероризму }\end{array}$ \\
\hline \multicolumn{2}{|c|}{ Ціль 2: Сприяння цілісності кордонів у всьому світі } \\
\hline $\begin{array}{ll}\text { - } & \text { Визначення напряму руху злочинців та жертв. } \\
\text { - } & \text { Донесення інформації до прикордонних служб. } \\
- & \text { Сприяння встановленню глобальних стандартів безпеки кордонів. } \\
- & \text { Допомога країнам-членам у підтримці цілісності їхніх документів про } \\
& \text { безпеку }\end{array}$ & $\begin{array}{l}\text { Налагодження комунікації між } \\
\text { правоохоронними органами та } \\
\text { прикордонною службою в } \\
\text { контексті взаємодії з Інтерполом, } \\
\text { що дозволить гарантувати безпеку } \\
\text { та розшук злочинців }\end{array}$ \\
\hline \multicolumn{2}{|l|}{ Ціль 3: Захист вразливих громад } \\
\hline $\begin{array}{ll}\text { - } & \text { Викриття злочинців та злочинів, пошук можливостей їх запобігання. } \\
- & \text { Захист жертв злочинів від експлуатації та повторної віктимізації. } \\
- & \text { Повага прав людини вразливих громад. } \\
- & \text { Розвиток надійної мережі експертів для обміну інформацією, } \\
& \text { передовою практикою та оперативною діяльністю. } \\
- & \text { Порушення елемента прибутку в кримінальній бізнес-моделі. } \\
- & \text { Виявлення та припинення незаконних фінансових потоків та } \\
& \text { прибутку, отриманих завдяки цій злочинній бізнес-моделі }\end{array}$ & $\begin{array}{l}\text { Визначення механізму входження в } \\
\text { практику правоохоронних органів } \\
\text { стандартів Інтерполу щодо обміну } \\
\text { інформацією, формування } \\
\text { експертної думки, виявлення та } \\
\text { порушення незаконних фінансових } \\
\text { потоків }\end{array}$ \\
\hline \multicolumn{2}{|c|}{ Ціль 4: Забезпечення віртуального простору для людей та бізнесу } \\
\hline $\begin{array}{ll}\text { - } & \text { Встановлення партнерських стосунків для забезпечення } \\
\text { кіберпростору. } & \\
\text { - } & \text { Розширення експертизи щодо розслідування кіберзлочинів. } \\
\text { - } & \text { Захист громад шляхом встановлення стандартів, державної освіти. } \\
\text { - } & \text { Захист критичної інфраструктури }\end{array}$ & $\begin{array}{l}\text { Удосконалення держави за такими } \\
\text { напрямами: стандарти кіберзахисту } \\
\text { та державне регулювання протидії } \\
\text { кіберзлочинам; фінансування } \\
\text { захисту критичної інфраструктури }\end{array}$ \\
\hline \multicolumn{2}{|l|}{ Ціль 5: Сприяння глобальній цілісності } \\
\hline $\begin{array}{ll}\text { - } & \text { Сприяння гідному управлінню та верховенству права. } \\
\text { - } & \text { Посилення експертизи щодо розслідування корупції. } \\
- & \text { Сприяння культурі доброчесності там, де корупція неприйнятна. } \\
- & \text { Побудова механізму підтримки та захисту цілісності й відновлення } \\
& \text { викрадених активів }\end{array}$ & $\begin{array}{l}\text { Розробка напрямів } \\
\text { антикорупційної політики в } \\
\text { правоохоронних органах, що } \\
\text { підвищить ефективність реалізації } \\
\text { державної політики у сфері } \\
\text { запобігання та протидії } \\
\text { економічним злочинам }\end{array}$ \\
\hline \multicolumn{2}{|c|}{ Ціль 6: Приборкання незаконних ринків } \\
\hline $\begin{array}{ll}\text { - } & \text { Підвищення обізнаності громадськості про ризики, пов’язані } 3 \\
& \text { незаконними товарами та продуктами. } \\
\text { - } & \text { Побудова механізму для виявлення нових незаконних ринків. } \\
\text { - } & \text { Посилення спроможності розслідування та запобігання незаконній } \\
& \text { торгівлі, включаючи їі фінансування. } \\
\text { - } & \text { Виявлення та порушення незаконного фінансового потоку та } \\
& \text { прибутку, отриманих внаслідок цього виду злочинної діяльності. } \\
\text { - } & \text { Викриття та припинення мережі організованої злочинності та наркотиків }\end{array}$ & $\begin{array}{l}\text { Зазначена ціль повністю відповідає } \\
\text { проблемам державної політики у } \\
\text { сфері запобігання та протидії } \\
\text { економічній злочинності щодо } \\
\text { протиправної економічної } \\
\text { діяльності, легалізації доходів } \\
\text { отриманих злочинним шляхом, } \\
\text { протидії наркотикам та } \\
\text { організованій злочинності }\end{array}$ \\
\hline \multicolumn{2}{|c|}{ Ціль 7: Підтримка екологічної безпеки та стійкості } \\
\hline $\begin{array}{ll}\text { - } & \text { Посилення спроможності розслідування екологічних злочинів. } \\
\text { - } & \text { Захист ресурсозалежних громад, вразливих видів та природної спадщини. } \\
\text { - } & \text { Побудова механізму захисту біорізноманіття та природних ресурсів. } \\
\text { - } & \text { Припинення мережі організованої злочинності та елемента прибутку. } \\
\text { - } & \text { Виявлення та порушення незаконного фінансового потоку і прибутку, } \\
& \text { отриманих внаслідок цього виду злочинної діяльності }\end{array}$ & $\begin{array}{l}\text { У цьому контексті є потреба } \\
\text { трансформації державної політики } \\
\text { та діяльності правоохоронних } \\
\text { органів щодо економічної } \\
\text { діяльності у сфері незаконного } \\
\text { використання природних ресурсів }\end{array}$ \\
\hline
\end{tabular}

Отже, Інтерпол є міжнародною інституцією з боротьби з різними видами злочинів, у тому числі економічними. Варто зауважити, що під час реалізації державної політики у сфері запобігання та протидії економічній злочинності варто враховувати технічні, інформаційні та організаційні можливості Інтерполу. Відповідно, система державного управління має повною мірою забезпечити можливості використання потенціалу Інтерполу вітчизняними правоохоронними організаціями. В Україні функціонує Регіональне центральне бюро Інтерполу, яким є Міністерство внутрішніх справ України. 
Сучасна система державного регулювання такої співпраці має низку недоліків, адже не повністю дозволяє використати потенціал Інтерполу для запобігання та протидії економічній злочинності (табл. 5).

Таблиия 5

Особливості державного регулювання процедур взаємодії з Інтерполом

\begin{tabular}{|c|c|c|c|}
\hline Документ & Рік & Зміст & Видавець \\
\hline $\begin{array}{c}\text { Указ } \\
\text { Президента }\end{array}$ & 2004 & $\begin{array}{l}\text { «Про представника Національного центрального бюро Інтерполу України } \\
\text { у Міжнародній організації кримінальній поліції - Інтерпол» }\end{array}$ & $\begin{array}{l}\text { Президент } \\
\text { України }\end{array}$ \\
\hline $\begin{array}{l}\text { Постанова } \\
\text { КМУ }\end{array}$ & 1992 & «Про вступ України до Інтерполу» & КМУ \\
\hline $\begin{array}{l}\text { Постанова } \\
\text { КМУ }\end{array}$ & 1993 & «Про Національне центральне бюро Інтерполу» & КМУ \\
\hline $\begin{array}{l}\text { Постанова } \\
\text { КМУ }\end{array}$ & 2004 & $\begin{array}{l}\text { «ро представника Національного центрального бюро Інтерполу в } \\
\text { Україні в Інтерполі» }\end{array}$ & КМУ \\
\hline Інструкція & 1997 & $\begin{array}{l}\text { «Про порядок використання правоохоронними органами можливостей } \\
\text { НЦБ Інтерполу в Україні у попередженні, розкритті та розслідуванні } \\
\text { злочинів, затверджена спільним наказом МВС, СБУ, ДМС, } \\
\text { Генпрокуратури, Держприкордону, ДПА» }\end{array}$ & $\mathrm{MBC}$ \\
\hline Наказ & 1998 & $\begin{array}{l}\text { «Про затвердження Інструкції про порядок приймання-передавання осіб, } \\
\text { які перебувають під вартою, на кордоні України та за ії межами» }\end{array}$ & $\begin{array}{l}\text { ДКСОДК та } \\
\text { МВС }\end{array}$ \\
\hline Наказ & 2004 & $\begin{array}{l}\text { «Про оперативний обмін інформацією щодо культурних цінностей, } \\
\text { оголошених у національний та міжнародний розшук» }\end{array}$ & $\begin{array}{l}\text { Мінкультури, } \\
\text { МВС }\end{array}$ \\
\hline Наказ & 1995 & «Про створення підрозділів Укрбюро Інтерполу» & $\mathrm{MBC}$ \\
\hline Наказ & 2005 & $\begin{array}{l}\text { «ро затвердження Інструкції з організації розшуку обвинувачених, } \\
\text { підсудних осіб, які ухиляються від відбування кримінального покарання, } \\
\text { безвісно зниклих осіб та встановлення особи невпізнаних трупів» }\end{array}$ & MBC \\
\hline Наказ & 2005 & $\begin{array}{l}\text { «Про затвердження Порядку залучення радників Національним } \\
\text { центральним бюро Інтерполу» }\end{array}$ & $\mathrm{MBC}$ \\
\hline Інструкція & 2009 & $\begin{array}{l}\text { «Про порядок виїзду конвойних груп МВС у службові відрядження за кордон } \\
\text { для приймання за межами України осіб, які перебувають під вартою» }\end{array}$ & $\mathrm{MBC}$ \\
\hline Наказ & 2011 & $\begin{array}{l}\text { «Про затвердження Інструкції про порядок прийняття органами } \\
\text { внутрішніх справ України рішень про заборону в’їзду в Україну } \\
\text { іноземцям та особам без громадянства» }\end{array}$ & $\mathrm{MBC}$ \\
\hline Наказ & 2012 & «Про затвердження Положення про Робочий апарат Укрбюро Інтерполу» & $\mathrm{MBC}$ \\
\hline
\end{tabular}

Отже, вітчизняна державна політика у сфері запобігання та протидії економічній злочинності має враховувати глобальні цілі Інтерполу й визначати механізми реалізації завдань, які відповідали б його діяльності та повною мірою дозволяли б використати цей потенціал. Вважаємо за необхідне під час формування положень щодо діяльності правоохоронних органів завжди враховувати положення про взаємодію з Інтерполом. Відповідна політика має реалізовуватися через такі механізми:

- економічний механізм - держава має визначати особливості фінансування: спільних операцій 3 Інтерполом; перебування та участь представників України в Генеральній Асамблеї; процесу реформування діяльності правоохоронних органів відповідно до цілей Інтерполу; фінансування Національного центрального бюро та інші заходи;

- правовий механізм має забезпечити гармонізацію національного законодавства у сфері запобігання та протидії економічній злочинності 3 процесуальними нормами Інтерполу, а також встановити правовий статус діяльності Національного центрального бюро Інтерполу;

- інформаційний механізм спрямований на поширення інформації у суспільстві про значення та роль Інтерполу в Україні й права та обов'язки Національного центрального бюро у процесах запобігання й протидії економічній злочинності;

- організаційний механізм - важливе значення для функціонування Національного центрального бюро Інтерполу в Україні має питання організаційної підпорядкованості, підзвітності та налагодження комунікаційних каналів щодо економічних злочинів. Організаційний механізм спрямований на підвищення ефективності комунікації між Інтерполом та правоохоронними органами щодо запобігання та протидії економічній злочинності;

- контрольний механізм - для оцінки ефективності реалізації державної політки у сфері запобігання та протидії економічній злочинності в частині взаємодії з Інтерполом необхідним $\epsilon$ проведення контрольних заходів щодо діяльності правоохоронних органів як за окремими справами, так і усією діяльністю в цілому. Контрольна функція держави покликана виявити критичні точки та на основі їх аналізу встановити причинно-наслідкові зв’язки й сформувати пропозиції щодо удосконалення як окремого механізму, так і політики в цілому. 
Кожен із зазначених механізмів має забезпечити ефективне використання ресурсів та підтримки, що надає Інтерпол. Так щодо оперативно-розшукової діяльності це є підтримка поліції в режимі реального часу; команди реагування; навчання та підготовка до розгортання. Щодо використання ресурсів автоматизована система пошуку для віддаленого пошуку баз даних Інтерполу; звіти аналітичного підрозділу кримінальної розвідки для вивчення зв'язків між підозрюваними, злочинами та місцезнаходженням; автоматична система ідентифікації відбитків пальців; база даних про втрачені проїзні документи; база ДНК; технологія MIND / FIND, яка дозволяє країнам надавати своїм передовим офіцерам доступ в реальному часі до баз даних. Щодо навчання - навчання фронтових офіцерів і користувачів базами даних, якими володіє Інтерпол.

Отже, розглянуті особливості діяльності Інтерполу визначили напрями розвитку механізмів формування та реалізації державної політики у сфері запобігання і протидії економічній злочинності. Це дозволяє налагодити ефективну співпрацю між Інтерполом та вітчизняними правоохоронними органами.

Європол. Вітчизняні дослідники П.Каркач та М.Копетюк наголошують, що «співпраця між державами-членами ЄС в галузі правоохоронної діяльності пов'язана із загальноєвропейською інтеграцією. Тому для України дослідження питань співпраці держав-членів ЄС в галузі правоохоронної діяльності $\epsilon$ важливим. Певною особливістю сучасного стану $\epsilon$ посилення міжвідомчої співпраці правоохоронних та судових органів країн-членів СС, утворення спеціальних структур, які відіграють важливу роль у боротьбі зі злочинністю, крім національних правоохоронних органів - це Свропейська поліція (Свропол) і Євроюст, які виконують конкретні завдання взаємної допомоги, координують зусилля між органами поліції, митної служби, імміграції та юстиції ЄС» [9].

«Свропол є регіональною міжнародною урядовою організацією правоохоронного характеру, що бере активну участь у протидії злочинності в рамках Європейського Союзу. Створення ії передбачено ще у договорі про Свропейські Співтовариства. Його історія починається 3 «TREVI» - Форуму внутрішньої безпеки Європейських економічних співтовариств / Європейського Союзу, який був створений у 1975 році та діяв до вступу в дію Маастрихтського договору (1993 рік)» [10].

«Створення Європолу стало можливим завдяки активному лобіюванню цієї ідеї урядовими колами Федеративної Республіки Німеччини (характерно, що в Німеччині досить давно дискутувалося питання щодо можливостей створення наднаціональної поліцейської служби на зразок «європейського ФБР»). Пропозиція тодішнього федерального канцлера ФРН Гельмута Коля, підтримана президентом Франції Франсуа Міттераном, щодо побудови спільної європейської служби кримінальної поліції для боротьби 3 незаконним поширенням наркотиків та іншими тяжкими формами організованої злочинності, була схвалена на засіданні Ради Європи у Люксембурзі (липень 1991 року). У Маастрихтській угоді про утворення Європейського Союзу від 7 лютого 1992 року був підтверджений намір заснувати європейську поліцейську службу для покращення співробітництва між країнами-членами ЄС у боротьбі з торгівлею наркотичними речовинами, тероризмом та іншими тяжкими формами міжнародної організованої злочинності. Для розробки концепції перспективної діяльності служби вже 2 червня 1992 року у Страсбурзі було створено інтернаціональний штаб у складі близько 20 представників національних служб кримінальної поліції Франції, Італії, Бельгії, Великобританії, Федеративної Республіки Німеччини та Нідерландів. Європолу на початковому етапі становлення (до підписання відповідної Конвенції) відводилася роль спеціалізованої координаційної установи по протидії наркоторгівлі (Europol Drugs Unit - EDU), про що було заявлено 2 червня 1993 року на нараді міністрів внутрішніх справ і юстиції країн-членів ЄС. Саме такий статус він мав 3 січня 1994 року, коли при штаб-квартирі ЄС у Гаазі було відкрито представництво Європолу як координаційної інстанції по боротьбі з наркобізнесом» [11].

Історію створення та функціонування Європолу представлено ключовими датами у таблиці 6.

«Верховною Радою України ратифіковано Угоду між Україною та Свропейським поліцейським офісом про стратегічну співпрацю. Угодою передбачено посилення співробітництва держав-членів Європейського Союзу, які діють через Європол, з Україною щодо запобігання серйозних форм міжнародної злочинності, їхнього виявлення, припинення та розслідування, зокрема шляхом обміну стратегічною та технічною інформацією. Передбачено, що Україна призначає Міністерство внутрішніх справ діяти в якості національного контактного пункту між Європолом та іншими компетентними органами України. Засідання на високому рівні між Сврополом і компетентними органами України проводяться регулярно для обговорення питань, які стосуються цієї угоди і співробітництва в цілому. Контактний пункт, призначений Україною, і той, який призначений Сврополом, проводять між собою регулярні консультації 3 питань політики і питань, що представляють взаємний інтерес, 3 метою виконання їхніх завдань і координації відповідних дій. Обмін інформацією, яка визначається угодою, здійснюється тільки на передбачених нею умовах. Інформація, обмін якою здійснено згідно з договором, використовується тільки для цілей угоди і під час розслідування, кримінального переслідування, запобігання кримінальному правопорушенню і процесуальним діям, що пов'язані з кримінальними справами. Обмін інформацією не стосується питань взаємного надання правової допомоги у кримінальних справах. У результаті цього ніякі положення угоди не перешкоджають положенням будь- 
якої угоди про надання взаємної правової допомоги, здійснення робочих контактів правоохоронних органів або будь-яким іншим угодам чи домовленостям щодо обміну інформацією між Україною і будьякою державою-членом Свропейського Союзу, не стосуються їх жодним чином і не впливають на них».

Таблиия 6

Хронологія розвитку Сврополу як регіонального правоохоронного органу

\begin{tabular}{|c|c|}
\hline Рік & Подія \\
\hline 1970 & Створено групу ТРЕВI міністрами внутрішніх справ та юстиції Європейських Співтовариств \\
\hline 1991 & $\begin{array}{l}\text { Створено Центральноєвропейське слідче управління (Свропол) для боротьби } 3 \text { міжнародним обігом } \\
\text { наркотиків та організованою злочинністю }\end{array}$ \\
\hline 1993 & За домовленістю міністрів створено відділ наркотиків Європолу (EDU) \\
\hline 1994 & Розпочато діяльність EDU у Гаазі \\
\hline 1995 & Засновано Європол відповідно до Конвенції на основі статті КЗ Маастрихтського договору \\
\hline 1999 & Призначено першого директора Європолу - колишнього координатора EDU \\
\hline 1999 & $\begin{array}{l}\text { Представлено Analysis Work File (AWF) - один з найперших інструментів Європолу для збору, обміну та } \\
\text { обробки інформації і розвідувальних даних }\end{array}$ \\
\hline 1999 & Вперше опубліковано щорічний звіт про організовану злочинність \\
\hline 2000 & Прийнято рішення про створення Інформаційної системи Сврополу (EIS) \\
\hline 2001 & Підписано перші угоди про співпрацю з третіми сторонами (Ісландія та Норвегія) \\
\hline 2001 & Створено робочу групу з боротьби з тероризмом при Європолі \\
\hline 2002 & Створено інструмент безпечного обміну інформацією Європолу \\
\hline 2002 & Підписано Угоду про співпрацю із США \\
\hline 2005 & $\begin{array}{l}\text { Охоплено } 500 \text { співробітників, офіцерів зв'язку, відряджених національних експертів, слухачів та } \\
\text { підрядників }\end{array}$ \\
\hline 2006 & Європолом прийнято 100 офіцерів зв’язку \\
\hline 2006 & Вперше опубліковано оцінку загрози організованої злочинності \\
\hline 2007 & Вперше опубліковано звіт про ситуацію та тенденції тероризму в СС \\
\hline 2009 & Запущено програму безпечного обміну інформацією Європолу \\
\hline 2010 & Європол став агенцією СС \\
\hline 2011 & Відбулася перша європейська конвенція керівників поліції \\
\hline 2013 & Відкрито Європейський центр з кіберзлочинності у Європолі \\
\hline 2015 & Європолом прийнято 200 офіцерів зв'язку \\
\hline 2015 & Запущено Спільну оперативну групу (JOT) MARE \\
\hline 2016 & Створено Європейський центр боротьби з тероризмом при Європолі \\
\hline 2016 & Запущено вебсайт «Найбільш розшукувані втікачі у Свропі» \\
\hline 2016 & Створено Європейський центр контрабанди мігрантів при Європолі \\
\hline 2016 & У гарячих точках Греції та Італії розміщено гостьових офіцерів \\
\hline 2017 & $\begin{array}{l}\text { Згідно з новим розпорядженням офіційну назву Європолу змінено } \\
\text { на Агентство Європейського Союзу з питань співпраці у правоохоронних органах }\end{array}$ \\
\hline
\end{tabular}

Висновки та перспективи подальших досліджень. Таким чином, важливе значення сьогодні покладається на міжнародне співробітництво у сфері запобігання та протидій економічній злочинності, яке за суб'єктною ознакою поділяється на глобальне та регіональне. Охарактеризовано глобальні й регіональні міжнародні правоохоронні організації та зазначено, що на цей час Україна співпрацює 3 двома організаціями, а саме: глобальною - Інтерпол та регіональною - Свропол. Розглянуто особливості функціонування зазначених правоохоронних організацій та особливості їх взаємодії 3 вітчизняними правоохоронними органами у сфері запобігання і протидії економічній злочинності. Охарактеризовано складові організаційної структури Інтерполу (Генеральну Асамблею, Виконавчий комітет, Президента Інтерполу, Генеральний секретаріат). Наведено характеристику діяльності директоратів Генерального секретаріату Інтерполу. Зроблено висновок, що загальні напрями розвитку державної політики у сфері запобігання та протидії економічній злочинності в контексті діяльності Інтерполу варто розглядати 3 огляду на цілі та стратегії розвитку Інтерполу. Отже, вітчизняна державна політика у сфері запобігання та протидії економічній злочинності має враховувати глобальні цілі Інтерполу та визначати механізми реалізації завдань, які відповідали б його діяльності та повною мірою дозволяли б використовувати цей потенціал. Вважаємо за необхідне під час формування положень щодо діяльності правоохоронних органів завжди враховувати положення про взаємодію з Інтерполом.

\section{Список використаної літератури:}

1. Войціховський А.В. Міжнародне співробітництво у боротьбі зі злочинністю як пріоритетний напрямок зовнішньої політики України / А.В. Войціховський // Право і безпека. - 2010. - № 3 (35) [Електронний pecypc]. - Режим доступу : https://core.ac.uk/download/pdf/187223272.pdf. 
2. Никитина И.Э. Сотрудничество европейских государств в сфере экспертно-криминалистической и оперативно-розыскной деятельности в рамках интеграционных и межправительственных объединений : дис. ... д.ю.н. : спец. 12.00.12 «Криминалистика; судебно-экспертная деятельность; оперативно-розыскная деятельность / И.Э. Никитина. - Москва, 2017.

3. Бирюков П.Н. Право международных организаций : учеб. пособ. / П.Н. Бирюков. - 2-е изд., пер. и доп. ; Сер. 63 Бакалавр. Академический курс. Модуль. - М. : Юрайт, 2017. - С. 140.

4. Губернская A.A. Правовое регулирование деятельности международных полицейских организаций : дис. ... к.ю.н. : спец. 12.00.10 «Международное право; Европейское право» / А.А. Губернская. - Москва, 2018.

5. Інтерпол: як працює міжнародна організація кримінальної поліції? [Електронний ресурс]. - Режим доступу : https://ukrainepravo.com/scientific-thought/legal_analyst/interpol-yak-pratsyuye-mizhnarodnaorganizatsiya-kryminalnoyi-politsiyi/.

6. Волеводз А.Г. Международная организация уголовной полиции - Интерпол и тенденция формирования региональных правоохранительных организаций / А.Г. Волеводз [Электронный ресурс]. - Режим доступа : https://mgimo.ru/upload/iblock/39e/39e2db62337d919c05b15bd9316f2139.pdf.

7. The Secretary General is the Organization's chief full-time official. The current Secretary General is Jürgen Stock [Electronic resource]. - Access mode : https://www.interpol.int/Who-we-are/General-Secretariat/Secretary-General.

8. The European Union is a key partner for us in fighting crime and terrorism [Electronic resource]. - Access mode : https://www.interpol.int/Our-partners/International-organization-partners/INTERPOL-and-the-European-Union.

9. Каркач П. Особливості нормативно-правового регулювання координації діяльності правоохоронних органів держав-членів Європейського Союзу / П.Каркач, М.Копетюк // Історико-правовий часопис. - 2015. - № 1. C. 46-50 [Електронний ресурс]. - Режим доступу : http://nbuv.gov.ua/UJRN/ipch_2015_1_12.

10. Проневич O.C. Європол: правові та організаційні засади участі у боротьбі з транснаціональною злочинністю / О.С. Проневич // Вісник Запорізького державного університету. - 2003. - № 1 [Електронний pecypc]. - Режим доступу : https://web.znu.edu.ua/herald/issues/archive/articles/2724.pdf.

11. Неволя В.В. Керівник Робочого апарату Укрбюро Інтерполу. Інтерпол та Європол: співвідношення діяльності міжнародних організацій в боротьбі з організованою злочинністю / В.В. Неволя [Електронний pecypc]. - Режим доступу : http://irbis-nbuv.gov.ua/cgi-bin/irbis_nbuv/cgiirbis_64.

\section{References:}

1. Vojcihovs'kyj, A.V. (2010), «Mizhnarodne spivrobitnyctvo u borot'bi zi zlochynnistju jak priorytetnyj naprjamok zovnishn'oi' polityky Ukrai'ny», Pravo $i$ bezpeka, No. 3 (35), [Online], available at: https://core.ac.uk/download/pdf/187223272.pdf

2. Nikitina, I.E. (2017), «Sotrudnichestvo evropeiskikh gosudarstv v sfere ekspertno-kriminalisticheskoi i operativnorozysknoi deyatel'nosti v ramkakh integratsionnykh i mezhpravitel'stvennykh ob"edinenii», D.Sc. Thesis of dissertation, spets. 12.00.12 «Kriminalistika; sudebno-ekspertnaya deyatel'nost'; operativno-rozysknaya deyatel'nost, Moskva.

3. Biryukov, P.N. (2017), Pravo mezhdunarodnykh organizatsii, ucheb. posob., ', 2nd ed., per. i dop., Ser. 63 Bakalavr. Akademicheskii kurs. Modul, Yurait, M., p. 140.

4. Gubernskaya, A.A. (2018), «Pravovoe regulirovanie deyatel'nosti mezhdunarodnykh politseiskikh organizatsii», Ph.D. Thesis of dissertation, spets. 12.00.10 «Mezhdunarodnoe pravo; Evropeiskoe pravo», Moskva.

5. «Interpol: jak pracjuje mizhnarodna organizacija kryminal'noi' policii'?», [Online], available at: https://ukrainepravo.com/scientific-thought/legal_analyst/interpol-yak-pratsyuye-mizhnarodna-organizatsiyakryminalnoyi-politsiyi/

6. Volevodz, A.G., «Mezhdunarodnaya organizatsiya ugolovnoi politsii - Interpol i tendentsiya formirovaniya regional'nykh pravookhranitel'nykh organizatsii», [Online], available at: https://mgimo.ru/upload/iblock/39e/39e2db62337d919c05b15bd9316f2139.pdf

7. «The Secretary General is the Organization's chief full-time official. The current Secretary General is Jürgen Stock», [Online], available at: https://www.interpol.int/Who-we-are/General-Secretariat/Secretary-General

8. «The European Union is a key partner for us in fighting crime and terrorism», [Online], available at: https://www.interpol.int/Our-partners/International-organization-partners/INTERPOL-and-the-European-Union

9. Karkach, P. and Kopetjuk, M. (2015), «Osoblyvosti normatyvno-pravovogo reguljuvannja koordynacii' dijal'nosti pravoohoronnyh organiv derzhav - chleniv Jevropejs'kogo Sojuzu», Istoryko-pravovyj chasopys, No. 1, pp. 46-50, [Online], available at: http://nbuv.gov.ua/UJRN/ipch_2015_1_12

10. Pronevych, O.S. (2003), «Jevropol: pravovi ta organizacijni zasady uchasti u borot'bi z transnacional'noju zlochynnistju», Visnyk Zaporiz'kogo derzhavnogo universytetu, No. 1, [Online], available at: https://web.znu.edu.ua/herald/issues/archive/articles/2724.pdf

11. Nevolja, V.V., «Kerivnyk Robochogo aparatu Ukrbjuro Interpolu. Interpol ta Jevropol: spivvidnoshennja dijal'nosti mizhnarodnyh organizacij $\mathrm{v}$ borot'bi $\mathrm{z}$ organizovanoju zlochynnistju», [Online], available at: http://irbisnbuv.gov.ua/cgi-bin/irbis_nbuv/cgiirbis_64

Грицишен Димитрій Олександрович - доктор економічних наук, професор, заслужений економіст України, декан факультету публічного управління та права Державного університету «Житомирська політехніка».

Наукові інтереси:

- реалізація державної кримінальної політики в сфері запобігання та протидії економічній злочинності;

- оцінювання безпеки України як середовища поширення економічної злочинності. 